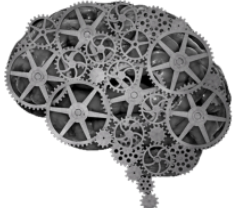

COMPANY GROUP "INTELLEKT"

Парфёнов Р. А., Пичхидзе С.Я. СГТУ им. Ю.А. Гагарина

Саратов, Россия

doi: 10.18411/lj2016-3-29

\title{
Усовершенствование конструкции локтевого эндопротеза
}

Для лечения повреждений локтевого сустава обычно применяются технологии остеосинтеза суставных фрагментов костей, эндопротезирование сустава и артроскопические техники для коррекции внутренних структур сустава $[1 \ldots 3]$.

Цель работы: усовершенствование конструкции эндопротеза локтевого сустава и нанесение нового комбинированного покрытия на поверхность выбранного эндопротеза.

Нами предлагаются следующие изменения в конструкцию прототипа [3]: 1) использовать посадку эндопротеза с натягом; 2) упростить место соединения ножек, убрав из конструкции прототипа полимерные втулку и вкладыш, 3) нанесение оксидного покрытия $\mathrm{Al}_{2} \mathrm{O}_{3}$ на эндопротез.
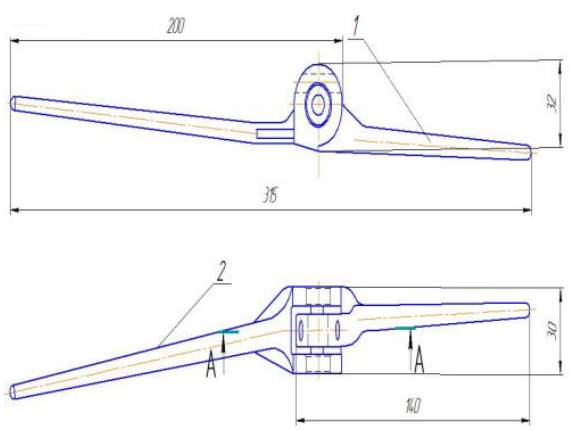

a

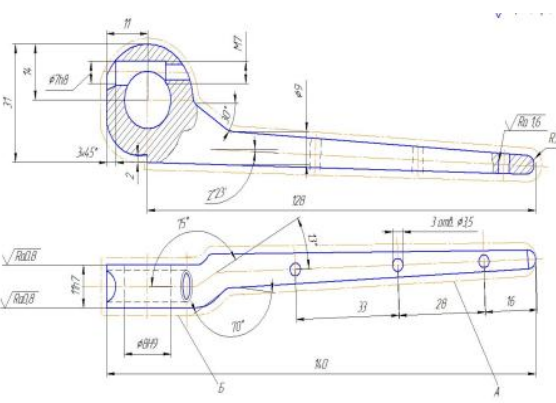

6
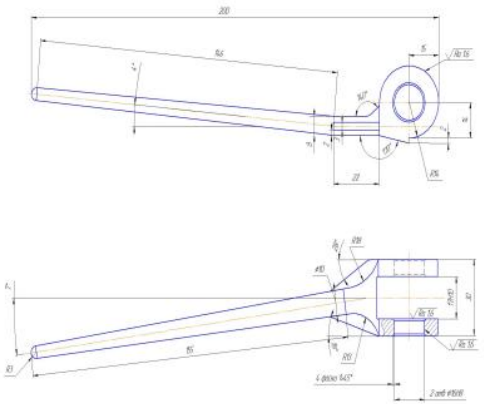
Конструкция эндопротеза локтевого сустава, где: а - прототип, б говершенствованная локтевая ножка, в - усовершенствованная плечевая ножка

Вывод: усовершенствован эндопротез локтевого сустава, предназначенный для замены поврежденного сустава искусственным аналогом. Нанесение на поверхность эндопротеза оксида алюминия делает конструкцию эндопротеза более прочной, тем самым увеличивая срок его службы.

\section{Литература:}

1. Слободской А.Б., Бадак И.С., Воронин И.В. и др. Эндопротезирование при лечении травм и заболеваний локтевого сустава //Остеосинтез и эндопротезирование: Материалы Междунар. Пироговскойнауч.-практ. конф. - М., 2008.

2. Эндопротезирование суставов.- 2010. [Электронный pecypc]. URL: http://www.orthoscheb.com/Page.aspx?page=./28209/28223/29160 (дата обращения 20.06.2013).

3. Патент РФ № 95111313 Российская Федерация, A61F2/38. Эндопротез локтевого сустава / Архипов С.В. - №95111313/14. заявл. 30.06.1995, опубл. 10.07.1997, Бюл. №26. - 5с. 